\title{
Dispensing and Variabilities in Pricing of Headache OTC Medicines by Community Pharmacies in a German Big City: A Simulated Patient Approach
}

\section{Christian Kunow (D) \\ Bernhard Langer (D)}

Department of Health, Nursing, Management, University of Applied Sciences Neubrandenburg, Neubrandenburg, Germany
Correspondence: Bernhard Langer Department of Health, Nursing, Management, University of Applied Sciences Neubrandenburg, Brodaer Straße 2, Neubrandenburg, 17033, Germany

Tel +49395 5693-3107

$\mathrm{Fax}+49395$ 5693-73107

Email langer@hs-nb.de
Background: In Germany, over-the-counter (OTC) medicines for self-medication may only be dispensed by community pharmacies (CPs). From the customer's point of view, "adequate" counseling includes not only the recommendation of medicines that meet guidelines, but also the dispensing of low-priced medicines. This is all the more important in Germany against the background of free pricing and a lack of obligation to display prices. The aim was to analyze the dispensing and possible price variability of OTC medicines for headache.

Methods: The cross-sectional design of the study based on the simulated patient methodology (SPM) included all 42 CPs of the German big city Potsdam and used eight trained simulated patients (SPs). Between October and December 2020, four different SPs visited each CP four times with two almost identical scenarios with the demand for a medicine for headache.

Results: All 168 planned visits were successfully completed and ibuprofen $(60.1 \%)$ was dispensed most frequently. Across all dispensed medicines, prices varied from $€ 0.93$ to $€ 9.97$ ( $\Delta 972 \%$; median $€ 3.46$ [interquartile range (IQR) $€ 2.25$ ]). For repeated dispensing of the same CPs, the price variability was a maximum of $€ 8.77$. In addition, packs with $\leq 10$ tablets were dispensed in $47.6 \%$, with 11 to 20 tablets in $50.6 \%$, and with $>20$ tablets in $1.8 \%$ of visits.

Conclusion: Increasing price transparency and strengthening price competition could make it easier for customers to access OTC medicines according to their personal needs.

Keywords: pricing, dispensing, OTC medicines, headache, community pharmacies, simulated patient

\section{Introduction}

Headache is one of the diseases with the highest prevalence worldwide. ${ }^{1}$ Since it belongs to the minor ailments, ${ }^{2}$ its medicinal treatment is also possible without a medical consultation. In this regard, headache is one of the most common causes of self-medication in Germany. ${ }^{3}$ In contrast to some other countries, ${ }^{4}$ in Germany such over-the-counter (OTC) medicines may only be dispensed by community pharmacies (CPs), whereby self-service is prohibited for customers. Dispensing and counseling on medicines must be carried out by a pharmacist with a 4-year degree in pharmacy and subsequent 12-month practical training in the $\mathrm{CP}$. However, it can also be carried out by non-pharmacists if the pharmacy manager has previously determined this in writing. ${ }^{5}$ The group of non-pharmacists largely comprises pharmaceutical technical assistants with a 2-year school education and 
subsequent 6-month practical training in the CP. In addition, this group includes other pharmaceutical professions (eg pharmacy technicians), in which, however, no new education has been provided for several years. In this context, the pharmacy staff must ensure "adequate" counseling. ${ }^{5}$ From the customer's point of view, this includes not only the recommendation of medicines that meet guidelines, but also economic aspects, eg the dispensing of low-priced medicines. ${ }^{6}$ These aspects are all the more important in Germany against the background of free pricing, ${ }^{7}$ a lack of obligation to display prices $^{8-10}$ and price communication that generally only takes place directly when the medicine is dispensed. As the first study worldwide, the aim was to analyze the dispensing and possible price variabilities of OTC medicines for headache.

\section{Methods}

\section{Study Design}

The cross-sectional design of the study, which was conducted between October 19 and December 5, 2020, was based on the simulated patient methodology (SPM), which is already frequently used internationally in CP settings. ${ }^{11}$ The SPM is a form of covert participatory observation by a person, who in an ideal case, is indistinguishable from a real customer (simulated patient, SP) and visits a CP to simulate a real-life situation based on a previously defined scenario. $^{11}$

\section{Setting and Sampling Technique}

All 42 CPs of the German big city Potsdam (December 31, 2019: 180,334 inhabitants; ranked \#43 among the biggest German cities ${ }^{12}$ ) were included. The SPs were eight individuals (five women and three men) with German ethnicity from a health-related department of the University of Applied Sciences Neubrandenburg, aged between 23 and 48 years. Four different SPs visited each CP with two almost identical scenarios four times (four SPs x 42 CPs $=168$ visits $=84$ visits per scenario) to increase the number of visits and thus the accuracy of the study results.

\section{Data Collection Tools and Approach}

The guideline of the German Federal Chamber of Pharmacists (BAK) on self-medication for headache ${ }^{13}$ formed the basis for two symptom-based scenarios, which included the demand for a medicine for headache and differed only in whether the demand was for oneself
Table I Self-Purchase Scenario

The SP entered the CP and said at the beginning of the conversation:

" $\mathrm{Hi}$, I need something for me for headache."

The SP did not have a particular product in mind.

When questioned by the pharmacy staff, the following information was provided by the SP:

\begin{tabular}{|l|l|}
\hline $\begin{array}{l}\text { Questions asked by the } \\
\text { Pharmacy Staff }\end{array}$ & $\begin{array}{l}\text { Information given by the } \\
\text { SP }\end{array}$ \\
\hline What symptoms occur? & $\begin{array}{l}\text { Mild press headache on both } \\
\text { sides } \\
\text { Since yesterday }\end{array}$ \\
$\begin{array}{l}\text { How long have the symptoms been } \\
\text { How often do the symptoms occur? } \\
\text { Have other symptoms occurred? } \\
\begin{array}{l}\text { Are there other medical conditions? } \\
\text { Which medications are taken } \\
\text { regularly? }\end{array}\end{array}$ & $\begin{array}{l}\text { No other symptoms } \\
\text { No other medical conditions }\end{array}$ \\
\hline
\end{tabular}

(self-purchase scenario) (Table 1) or for the boyfriend/ girlfriend (purchase for a third party scenario) (Table 2). The reason for this distinction is that both types of purchases occur in everyday pharmacy. ${ }^{14-17}$ For example, a customer survey in 2018 and 2019 specifically on OTC supply by Australian CPs determined that $24.5 \%$ of purchases were for a third party. ${ }^{17}$ The scenarios were designed as "normalscenarios", so that there should always be a dispensing of a medicine for this purpose. The SPs described their concerns to the pharmacy staff who first approached them and only provided further information when asked.

Table 2 Purchase for a Third Party Scenario

The SP entered the CP and said at the beginning of the conversation:
"Hi, my boyfriend/girlfriend needs something for headache."
The SP did not have a particular product in mind.
When questioned by the pharmacy staff, the following information
was provided by the SP:


Table 3 CPs, SPs, Pharmacy Staff and Visits Characteristics as well as Time and Type of Data Collection

\begin{tabular}{|l|c|c|}
\hline $\begin{array}{l}\text { CPs, SPs, Pharmacy Staff and Visits } \\
\text { Characteristics }\end{array}$ & $\begin{array}{c}\text { Time of Data } \\
\text { Collection }\end{array}$ & Type of Data Collection \\
\hline CP quality certificate & After the visit & Before the visit \\
Gender of the SPs & Before the visit & Exact measurement using a telephone query after completing all the visits \\
Age of the SPs & During the visit & Exact measurement based on the gender of the SPs \\
Gender of the pharmacy staff & During the visit & Exact measurement using visual impression of the SPs \\
Age of the pharmacy staff & After the visit & Estimate using visual impression of the SPs \\
Professional group of the pharmacy staff & During the visit & Exact measurement using a telephone query after completing all the visits \\
Time of the visit & During the visit & Exact measurement using the SPs' watch \\
Queue - patients waiting after the SP & Exact measurement using visual impression of the SPs \\
\hline
\end{tabular}

In total, there were four runs. These alternated with regard to the two scenarios, whereby the first run began with visits based on the self-purchase scenario. Between the individual runs there was a week's break in each case, in order not to simulate two almost identical scenarios in the same CPs too soon after each other and thus increase the risk of detection. A total of $€ 673.01$ was required to purchase the medicines, which was financed from the second author's own funds. Prior to data collection, it was ensured that all SPs were familiar with the theoretical aspects of SPM, the scenarios, and the content of the assessment form. To validate the scenarios and the planned assessment form - but also for practical training - the SPs conducted a total of 42 validation visits outside Potsdam. Video recordings to assess the performance of the SPs were not made, as otherwise the study design would no longer have been covert. However, after the validation visits, a workshop was held to share experiences and inform each other about the specifics of the scenarios and the assessment form.

On the assessment forms, the SPs first recorded numerous CPs, SPs, pharmacy staff and visits characteristics (see details in Table 3). Afterwards, the data on the individual medicines (active ingredient, package size, original vs generic drug, single drug substance vs fixed-dose combination, recommended vs not recommended drug, price) were recorded by comparing them with the respective sales slips, the package inserts, and the German dispensing recommendations. ${ }^{18}$

\section{Statistical Analysis}

Data were analyzed using SPSS version 26 for Windows (IBM, Armonk, NY, USA). Descriptive statistics were used to determine frequencies and percentages for categorical data. Application of the Shapiro-Wilk test revealed that the continuous data were not normally distributed. Therefore, the median, interquartile range [IQR], min., max. and range in \% were presented. A chi-square test (or alternatively, for expected cell frequencies below five, a Fisher's exact test $)^{19}$ was used in each case to identify possible associations between the data on the individual medicines (active ingredient, package size, original vs generic drug, single drug substance vs fixed-dose combination, recommended vs not recommended drug) and the CPs, SPs, pharmacy staff and visits characteristics. Cramer's V was reported as an effect size measure. For significant results of Fisher's exact test for contingency tables larger than $2 \times 2$, post-hoc analyses with pairwise Fisher's exact tests using a Bonferroni-Holm adjustment for multiple comparisons was performed. The nonparametric Mann-Whitney U-test (Pearson's $r$ was reported as a measure of effect size) and the KruskalWallis test (analogous to Field ${ }^{19}$ reporting of an effect size with more than one degree of freedom is omitted) were used to analyze whether the price of the individual medicines differs with respect to the CPs, SPs, pharmacy staff and visits characteristics. A p-value of less than 0.05 was considered as statistically significant in all analyses.

\section{Results}

All 168 planned visits were successfully carried out. Characteristics for the CPs, the SPs, the advising pharmacy staff and the visits are shown in Table 4.

The following medicines recommended for selfmedication in Germany ${ }^{18}$ were dispensed (one medicine per visit): $60.1 \%$ ibuprofen (101/168), $20.2 \%$ paracetamol (34/168), 4.8\% acetylsalicylic acid + paracetamol + caffeine $(8 / 168)$, and $4.2 \%$ acetylsalicylic acid (7/168). Nonrecommended medications ${ }^{18}$ dispensed were: $7.1 \%$ ibuprofen lysinate (12/168), 1.8\% acetylsalicylic acid + vitamin C (3/168), $1.2 \%$ ibuprofen + caffeine $(2 / 168)$, and $0.6 \%$ magnesium (1/168). $87.5 \%$ of the medicines dispensed were generics (147/168) and $12.5 \%$ were originals (21/168). 
Table 4 CPs, SPs, Pharmacy Staff and Visits Characteristics

\begin{tabular}{|c|c|c|}
\hline & Frequency (n) & Percentage (\%) \\
\hline All visits & 168 & 100 \\
\hline \multicolumn{3}{|l|}{$\mathrm{CP}$ quality certificate } \\
\hline - No & 76 & 45.2 \\
\hline - Yes & 76 & 45.2 \\
\hline $\begin{array}{l}\text { - Not able to be } \\
\text { determined }\end{array}$ & 16 & 9.6 \\
\hline \multicolumn{3}{|l|}{ Gender of the SPs } \\
\hline - Male & 84 & 50.0 \\
\hline - Female & 84 & 50.0 \\
\hline \multicolumn{3}{|l|}{ Age of the SPs } \\
\hline$\bullet<30$ & 102 & 60.7 \\
\hline - 30-49 & 66 & 39.3 \\
\hline$\bullet \geq 50$ & 0 & 0 \\
\hline \multicolumn{3}{|l|}{ Gender of the pharmacy staff } \\
\hline - Male & 30 & 17.9 \\
\hline - Female & 138 & 82.1 \\
\hline \multicolumn{3}{|l|}{ Age of the pharmacy staff } \\
\hline$\bullet<30$ & 16 & 9.5 \\
\hline - 30-49 & 91 & 54.2 \\
\hline - $\geq 50$ & 61 & 36.3 \\
\hline \multicolumn{3}{|l|}{ Professional group of the } \\
\hline - Pharmacist & 89 & 53.0 \\
\hline - Non-pharmacist & 72 & 42.8 \\
\hline $\begin{array}{l}\text { Not able to be } \\
\text { determined }\end{array}$ & 7 & 4.2 \\
\hline \multicolumn{3}{|l|}{ Time of the visit } \\
\hline - 8:00 a.m.-12:00 p.m. & 26 & 15.5 \\
\hline - 12:01 p.m.-4:00 p.m. & 85 & 50.6 \\
\hline • 4:0I p.m.-8:00 p.m. & 57 & 33.9 \\
\hline \multicolumn{3}{|l|}{$\begin{array}{l}\text { Queue - patients waiting } \\
\text { after the SP }\end{array}$} \\
\hline - No & 120 & 71.4 \\
\hline - Yes & 48 & 28.6 \\
\hline
\end{tabular}

Across all dispensed medicines, prices varied from $€ 0.93$ to $€ 9.97$ ( $\triangle 972 \%$; median $€ 3.46$ [IQR $€ 2.25]$ ). For repeated dispensings of the same $\mathrm{CPs}$, the price variability was a maximum of $€ 8.77$. At the level of various drug groups, the price range for single drug substances was between $€ 0.93$ and $€ 9.97$ ( $\triangle 972 \%$; median $€ 3.45$ [IQR $€ 1.92])$ and for fixed-dose combinations between $€ 3.46$ and $€ 8.21$ ( $\Delta$ 137\%; median $€ 5.99$ [IQR $€ 3.30]$ ). The price range for originals was between $€ 3.46$ and $€ 8.21$ ( $\Delta$ 137\%; median €5.99 [IQR €3.27]) and for generics between $€ 0.93$ and $€ 9.97$ ( $\Delta 972 \%$; median $€ 3.36$ [IQR $€ 1.50])$. For the recommended medicine ibuprofen, the price range was between $€ 1.55$ and $€ 6.50$ ( $\triangle 319 \%$; median $€ 3.46$ [IQR $€ 1.05]$ ), whereas for the non-recommended medicine ibuprofen lysinate, the price range was between $€ 4.95$ and $€ 9.97$ ( $\triangle 101 \%$; median $€ 8.68$ [IQR $€ 3.96]$ ). In addition, packs with $\leq 10$ tablets were dispensed in $47.6 \%$ (80/168) of visits, with a price range between $€ 0.93$ and $€$ 7.50 ( $\triangle 706 \%$; median $€ 2.91$ [IQR $€ 1.13$ ]). Packs containing 11 to 20 tablets were dispensed in 50.6\% (85/168) of visits, with a price range between $€ 1.55$ and $€ 9.97$ ( $\Delta$ $543 \%$; median $€ 3.95$ [IQR €3.25]). Packs of more than 20 tablets were dispensed in $1.8 \%(3 / 168)$ of visits, with a price range between $€ 4.83$ and $€ 5.31$ ( $\Delta 10 \%$; median $€ 5.31$ [IQR not calculable]).

Table 5 shows the associations between the data on the individual medicines (active ingredient, package size, original vs generic drug, single drug substance vs fixed-dose combination, recommended vs not recommended drug, price) and the CPs, SPs, pharmacy staff and visits characteristics. There was a significant association between package size and age of the pharmacy staff (Fisher's exact test; $p=0.043, V=0.201$ ), whereby the effect size V according to Cohen corresponded to a "small" effect. ${ }^{20}$ In post-hoc analyses, no significant associations were found. In addition, package size and the presence of a queue showed a significant association (Fisher's exact test; $\mathrm{p}=0.030, \mathrm{~V}=0.219$ ), with a "small" effect according to Cohen. ${ }^{20}$ Post-hoc analyses also showed no significant correlation. A significantly higher median price was found when older SPs were used (Mann-Whitney $U$-test; $U=2618.500, p=$ $0.015, r=0.187$ ), whereby according to Cohen there was a "small" effect. ${ }^{20}$ If SPs under the age of 30 were used, the median price was $€ 3.36$ [IQR $€ 1.62]$ ) with a price range between $€ 0.93$ and $€ 9.97$ ( $\Delta 972 \%$ ). If SPs between 30 and 49 years of age were used, the median price was $€ 3.80[\mathrm{IQR}$ $€ 2.44])$ with a price range between $€ 1.36$ and $€ 9.72$ ( $\Delta 615 \%)$.

\section{Discussion}

The medicines dispensed by the pharmacy staff and their proportions differed in some cases significantly from those in comparative SPM studies, which were also conducted using symptom-based scenarios. For example, ibuprofen, which was dispensed most frequently in this SPM study, was rather rare (18.4\%) in a Jordanian SPM study with an almost identical scenario. ${ }^{21}$ In an Ethiopian SPM study, although ibuprofen was most frequently dispensed with $45.0 \%$, this was against the background that SPs reported when asked that they were already taking paracetamol 
Table 5 Association between Data on the Individual Medicines and CP, SPs, Pharmacy Staff and Visits Characteristics ( $\mathrm{n}=168$ )

\begin{tabular}{|c|c|c|c|c|c|c|}
\hline & $\begin{array}{c}\text { Active } \\
\text { Ingredient }\end{array}$ & Package Size & $\begin{array}{l}\text { Original vs } \\
\text { Generic Drug }\end{array}$ & $\begin{array}{c}\text { Single Drug } \\
\text { Substance vs Fixed- } \\
\text { Dose Combination }\end{array}$ & $\begin{array}{c}\text { Recommended } \\
\text { vs Not } \\
\text { Recommended } \\
\text { Drug }\end{array}$ & Price \\
\hline $\begin{array}{l}\mathrm{CP} \text { quality } \\
\text { certificate }\end{array}$ & $\begin{array}{l}0.160^{\mathrm{a}} \\
(0.238)\end{array}$ & $\begin{array}{l}0.378^{a} \\
(0.121)\end{array}$ & $\begin{array}{l}0.262^{\mathrm{a}} \\
(0.135)\end{array}$ & $\begin{array}{l}0.643^{\mathrm{a}} \\
(0.097)\end{array}$ & $\begin{array}{l}0.536^{\mathrm{a}} \\
(0.087)\end{array}$ & $0.463^{c}$ \\
\hline $\begin{array}{l}\text { Gender } \\
\text { SPs }\end{array}$ & $\begin{array}{l}0.672^{\mathrm{a}} \\
(0.172)\end{array}$ & $\begin{array}{l}0.368^{a} \\
(0.123)\end{array}$ & $\begin{array}{l}0.816^{\mathrm{b}} \\
(0.018)\end{array}$ & $\begin{array}{l}0.073^{\mathrm{b}} \\
(0.022)\end{array}$ & $\begin{array}{l}0.134^{\mathrm{b}} \\
(0.115)\end{array}$ & $\begin{array}{l}0.065^{\mathrm{d}} \\
(0.143)\end{array}$ \\
\hline $\begin{array}{l}\text { Age } \\
\text { SPs }\end{array}$ & $\begin{array}{l}0.437^{\mathrm{a}} \\
(0.193)\end{array}$ & $\begin{array}{l}0.224^{\mathrm{a}} \\
(0.125)\end{array}$ & $\begin{array}{l}0.403^{\mathrm{b}} \\
(0.064)\end{array}$ & $\begin{array}{l}0.263^{b} \\
(0.086)\end{array}$ & $\begin{array}{l}0.135^{\mathrm{b}} \\
(0.115)\end{array}$ & $\begin{array}{l}0.015^{\mathrm{d} *} \\
(0.187)\end{array}$ \\
\hline $\begin{array}{l}\text { Gender } \\
\text { pharmacy staff }\end{array}$ & $\begin{array}{l}0.069^{\mathrm{a}} \\
(0.279)\end{array}$ & $\begin{array}{l}0.068^{\mathrm{a}} \\
(0.188)\end{array}$ & $\begin{array}{l}0.54 I^{\mathrm{a}} \\
(0.059)\end{array}$ & $\begin{array}{l}0.468^{\mathrm{a}} \\
(0.077)\end{array}$ & $\begin{array}{l}1.000^{\mathrm{a}} \\
(0.011)\end{array}$ & $\begin{array}{l}0.414^{d} \\
(0.063)\end{array}$ \\
\hline $\begin{array}{l}\text { Age } \\
\text { pharmacy staff }\end{array}$ & $\begin{array}{l}0.468^{\mathrm{a}} \\
(0.197)\end{array}$ & $\begin{array}{l}0.043^{\mathrm{a} *} \\
(0.201)\end{array}$ & $\begin{array}{l}0.738^{a} \\
(0.072)\end{array}$ & $\begin{array}{l}0.696^{\mathrm{a}} \\
(0.095)\end{array}$ & $\begin{array}{l}0.134^{\mathrm{a}} \\
(0.149)\end{array}$ & $0.946^{c}$ \\
\hline $\begin{array}{l}\text { Professional group } \\
\text { pharmacy staff }\end{array}$ & $\begin{array}{l}0.146^{\mathrm{a}} \\
(0.235)\end{array}$ & $\begin{array}{l}0.535^{\mathrm{a}} \\
(0.096)\end{array}$ & $\begin{array}{l}0.590^{\mathrm{a}} \\
(0.099)\end{array}$ & $\begin{array}{l}0.187^{\mathrm{a}} \\
(0.158)\end{array}$ & $\begin{array}{l}0.484^{\mathrm{a}} \\
(0.106)\end{array}$ & $0.743^{c}$ \\
\hline $\begin{array}{l}\text { Time } \\
\text { of the visit }\end{array}$ & $\begin{array}{l}0.456^{\mathrm{a}} \\
(0.195)\end{array}$ & $\begin{array}{l}0.405^{\mathrm{a}} \\
(0.110)\end{array}$ & $\begin{array}{l}0.413^{\mathrm{a}} \\
(0.113)\end{array}$ & $\begin{array}{l}0.24 I^{\mathrm{a}} \\
(0.130)\end{array}$ & $\begin{array}{l}0.359^{a} \\
(0.118)\end{array}$ & $0.165^{c}$ \\
\hline $\begin{array}{l}\text { Queue - patients } \\
\text { waiting after the } \\
\text { SP }\end{array}$ & $\begin{array}{l}0.126^{\mathrm{a}} \\
(0.254)\end{array}$ & $\begin{array}{l}0.030^{\mathrm{a} *} \\
(0.219)\end{array}$ & $\begin{array}{l}1.000^{\mathrm{b}} \\
(0.000)\end{array}$ & $\begin{array}{l}1.000^{\mathrm{a}} \\
(0.014)\end{array}$ & $\begin{array}{l}0.115^{b} \\
(0.122)\end{array}$ & $\begin{array}{l}0.126^{d} \\
(0.118)\end{array}$ \\
\hline
\end{tabular}

Notes: ${ }^{a}$ Fisher's exact test $\mathrm{p}$-value (Cramer's V); ${ }^{\mathrm{b}}$ Chi-square test $\mathrm{p}$-value (Cramer's V); ${ }^{\mathrm{C}}$ Kruskal-Wallis test $\mathrm{p}$-value (analogous to Field, ${ }^{19}$ the reporting of an effect size for more than one degree of freedom is omitted); 'Mann-Whitney $U$-test $p$-value (Pearson's $r$ ); *significant at $P<0.05$.

without noticeable relief. ${ }^{22}$ In a Brazilian SPM study, when asked, SPs reported not taking medicines previously but not getting enough sleep and eating poorly. It turned out that the medicines dispensed and their proportions - with dipyrone or dipyrone and associations being the most frequently dispensed with $70.8 \%$ - were again different. ${ }^{23}$ These differences suggest an influence of the particular scenario used on the corresponding dispensing. ${ }^{24}$ In addition, the specific national dispensing recommendations, the personal preferences of both pharmacy staff and customers, and the medicines stocked in each CP may also play a role.

The extreme price variabilities determined in this SPM study are significantly larger compared to the variabilities of two quite recent German SPM studies for acute diarrhea in a medium-sized city with 84 visits. One SPM study calculated prices from $€ 2.28$ to $€ 10.98$ ( $\triangle 382 \%$ ) also using symptombased scenarios. ${ }^{24}$ In the other SPM study three years earlier, prices across symptom-based and medication-based scenarios ranged from $€ 2.36$ to $€ 8.49(\Delta 260 \%){ }^{25}$ In contrast to the present study, the most recent international SPM studies, which examined price variabilities only as a secondary objective, found smaller, but also in some cases significantly larger variabilities. In an Iraqi SPM study in Baghdad with 75 visits using a symptom-based scenario on acute diarrhea, prices ranged from $\$ 0.20$ to $\$ 1.38(\Delta 590 \%)^{26}$ and in a Malaysian SPM study in the state of Penang with 100 visits also using a symptom-based scenario on common cold even from $\mathrm{M} \$ 3.90$ to $\mathrm{M} \$ 37.00(\Delta 849 \%){ }^{27}$ For oral emergency contraceptives (EC), a Brazilian SPM study in three urban regions with 122 visits using a product-based scenario showed a somewhat lower range from "only" $\$ 1.25$ to $\$ 5.75$ ( $\Delta$ $360 \%$ ). ${ }^{28}$ However, a Congolese SPM study in Kinshasa with 73 visits also using a product-based scenario for oral EC showed even a range from $\$ 0.50$ to $\$ 9.20(\Delta 1.740 \%)$. ${ }^{29}$ In comparison to this and to the present SPM study, a SPM study in five geographic regions across the USA with 344 mystery calls using a medication-based scenario was able to determine even more significant price variabilities between $\$ 2.59$ and $\$ 1.200 .99(\Delta 46.270 \%)$, also for oral EC. ${ }^{30}$

These differences in the calculated price variabilities between the various SPM studies can be attributed to the very different composition of the study regions on the one 
hand and to the differently designed scenarios on the other. In addition, the CPs may be subject to different purchase prices for the medicines and have different operating costs. However, this can hardly account for the extreme variabilities, especially since in this study, analogous to some other SPM studies, ${ }^{26,29}$ significant variabilities were also found between CPs in the same city and thus in a narrowly defined area. Furthermore, enormous price differences occurred even for the smallest package size, accounting for a large proportion of the total price differences. This shows that package size is not the central driver of price differences. Rather, this could be due to the dispensing of higher-priced medicines, which is made possible by the prompt self-medication sought by customers for acute minor ailments and thus presumably lower price elasticity. ${ }^{31,32}$ In addition, the exploitation of the usually existing information asymmetry by the pharmacy staff may also play a role. Closely related to this could also be different profit expectations of the CPs, which are then reflected in price variabilities. The dispensing of higher-priced medicines in particular - which contribute to significant price variabilities, especially in symptom-based scenarios ${ }^{24}$ - could also be induced by the fact that both the pharmacy staff ${ }^{33-35}$ and customers $^{36-38}$ assume that such medicines are of higher quality. A very good example of this is the dispensing of the newer, more expensive (and so far not recommended in Germany) fixed-dose combination ibuprofen lysinate, which, however, was not more effective than the single drug substance ibuprofen in a recent clinical trial. ${ }^{39}$ Higher-priced medicines, however, may represent a financial burden for customers at a certain price threshold and thus a barrier to accessing the medicine they need. This could also have a negative impact on the recovery process.

For these reasons, CPs in Germany should be required by law to provide interactive information touch screens or price cards on the sales floor and to actively communicate prices during the consultation. In addition, pharmacy staff should be sensitized to inquire about the customer's price expectations if the information is not provided by the customer - as part of good quality of counseling. ${ }^{6}$ On the other hand, customers should be encouraged by publicly effective campaigns to inquire directly about low-priced medicines and to make price comparisons. However, the corresponding visits and calls are quite time-consuming for customers. Therefore, a database to be set up by law with the most up-to-date prices, implemented by an app to be set up according to preferred shopping locations, can facilitate comparisons.

In addition, this study showed that middle-aged SPs were sold higher-priced medications compared with younger SPs.
One reason could be that the higher average income of middle-aged individuals ${ }^{40,41}$ and thus their higher ability to pay, was taken into account by pharmacy staff for income motives when dispensing medications. Future studies should investigate this issue further. Moreover, in slightly more than half of all visits, the smallest package size was not dispensed. Since the guidelines of the BAK stipulate a maximum treatment duration of 3 days for headache, ${ }^{13}$ the question arises as to whether the dispensing of larger packs is always in line with demand. Although a larger pack could be cheaper per tablet, the problem can arise after dispensing that the customer only needs a small part of the pack after all and the rest remains unused until the expiry date. This can lead to avoidable medication waste, but also to unnecessary costs for customers. Pharmacy staff should therefore be required to explicitly inform customers about the different package sizes (and their prices) as well as the maximum treatment duration.

\section{Strengths and Limitations}

This study successfully applied - as did a study on price variabilities for prescription only medicines ${ }^{42}$ - the SPM, which is referred to as the "gold standard". 43 As a direct method, the SPM is preferable to the indirect method of the World Health Organization/Health Action International ${ }^{44}$ because it can determine the actual prices. ${ }^{42}$ As discussed in the literature, ${ }^{45}$ our SPM study also has limited external validity. First, the present SPM study referred only to a single big city and to medicines for acute headache. Moreover, only symptom-based scenarios were applied. On the other hand, the use of different scenarios and of several SPs of different gender and age may have positively influenced the external validity. However, it cannot be ruled out that dispensing behavior is different for customers with a different educational background (eg, non-academics) or ethnicity (eg, nonGerman ethnicity). In addition, some of the medicines dispensed in this study had different active ingredients, strengths, and package sizes. However, the aim was to identify possible price variabilities for medicines in everyday consultation. It was not possible to ask about the age of the consulting pharmacy staff, as there was a risk that the pharmacy staff would inform colleagues in the vicinity about the visits. The age estimates required as a result may have introduced some bias in the age variable. Contrary to recommendations in the literature, ${ }^{46}$ no audio recordings were made nor were second observers used for quality assurance of the visits. The reason for this is that in this study only objective data (eg, active ingredients and prices) were collected on the basis of official documents (eg, sales slips or package inserts). Therefore, recall 
bias ${ }^{47}$ and intra- and inter-observer variabilities typical of SPM studies ${ }^{48}$ can be excluded.

\section{Conclusion}

In Germany, enormous price variabilities were observed in a big city, which were also shown in subgroup analyses between repeated dispensings of the same CPs as well as within various drug groups. Measures to be taken primarily by the legislator should increase price transparency and strengthen price competition. This could reduce the enormous price variabilities and thus make it easier for customers to access OTC medicines according to their personal needs.

\section{Abbreviations}

$\mathrm{IQR}$, interquartile range; OTC, over-the-counter; CPs, community pharmacies; SPM, simulated patient methodology; SPs, simulated patients; BAK, German Federal Chamber of Pharmacies; EC, emergency contraceptives.

\section{Data Sharing Statement}

The datasets are available from the corresponding author upon reasonable request.

\section{Ethics Approval and Informed Consent}

The study protocol was approved by the institutional ethics committee of the Neubrandenburg University of Applied Sciences (registration number: HSNB/166/20). Due to the special study design (covert participant observation to avoid a "Hawthorne effect") necessary to achieve the study objectives, compliance with ethical study principles is particularly important. However, waiving participant consent in such studies is justified because it allows research to generate socially valuable information $^{49}$ and the risks to participating CPs are minimal. Thus, in accordance with the "Guideline for the Use of Mystery Research in Market and Social Research", 50 the data are processed in such a way that neither the CPs involved in the study nor their personnel can be identified. Nevertheless, to address the CPs' need for information, a letter informing them of the background and conduct of the study was sent to all participating CPs in early March 2020, in line with recommendations in the international literature ${ }^{49,51}$ and implementation in numerous studies. ${ }^{52-54}$ However, in order not to jeopardize the covert study design, a correspondingly long period of time was specified in this letter instead of a specific date for conducting the visits. Recruited persons provided their written informed consent to act as SPs.

\section{Author Contributions}

All authors made a significant contribution to the work reported, whether that is in the conception, study design, execution, acquisition of data, analysis and interpretation, or in all these areas; took part in drafting, revising or critically reviewing the article; gave final approval of the version to be published; have agreed on the journal to which the article has been submitted; and agree to be accountable for all aspects of the work.

\section{Funding}

We acknowledge support for the Article Processing Charge from the Deutsche Forschungsgemeinschaft (German Research Foundation, 414051096) and the Open Access Publication Fund of the Hochschule Neubrandenburg (Neubrandenburg University of Applied Sciences).

\section{Disclosure}

The authors declare that there is no conflict of interest.

\section{References}

1. GBD 2017 Disease and Injury Incidence and Prevalence Collaborators. Global, regional, and national incidence, prevalence, and years lived with disability for 354 diseases and injuries for 195 countries and territories, 1990-2017: a systematic analysis for the Global Burden of Disease Study 2017. Lancet. 2018;392 (10159):1789-1858. doi:10.1016/s0140-6736(18)32279-7

2. Paudyal V, Cunningham S, Gibson Smith K, et al. Methodological considerations in clinical outcomes assessment of pharmacy-based minor ailments management: a systematic review. PLoS One. 2018;13(10):e0205087. doi:10.1371/journal.pone.0205087

3. Eichenberg C, Auersperg F, Rusch BD, et al. Self-medication: a nationwide representative survey on motives, reasons and sources on consuming over-the-counter medication. Psychother Psychosom Med Psychol. 2015;65(8):304-310. doi:10.1055/s-0035-1545311

4. Oleszkiewicz P, Krysinski J, Religioni U, et al. Access to medicines via non-pharmacy outlets in European countries-a review of regulations and the influence on the self-medication phenomenon. Healthcare. 2021;9(2):123. doi:10.3390/healthcare9020123

5. ApBetrO. Ordinance on the Operation of Pharmacies in the version as published on September 26, 1995 (Federal Law Gazette I p. 1195), last amended pursuant to Article 1a of the Law for the implementation of Directives (EU) 2015/566 and (EU) 2015/565 on the import and the coding of human tissues and tissues preparations on November 21, 2016 (Federal Law Gazette I p. 2623); 2016. Available from: https:// www.abda.de/fileadmin/assets/Gesetze/ApBetrO_eng1_Stand-2016-12. pdf. Accessed February 7, 2021.

6. Brodsky SD, Awosika OD, Eleryan MG, et al. Patient awareness of local drug price variation and the factors that influence pharmacy choice: a cross-sectional survey study. J Drugs Dermatol. 2017;16 (12):1274-1280.

7. AMG. Medicinal Products Act in the version published on 12 December 2005 (Federal Law Gazette [BGBl.]) Part I p. 3394, last amended by Article 11 of the Act of 6 May 2019 (Federal Law Gazette I p. 646); 2019. Available from: http://www.gesetze-im-internet.de/englisch_amg/eng lisch_amg.pdf. Accessed February 7, 2021. 
8. PAngV. Preisangabenverordnung in der Fassung der Bekanntmachung vom 18. Oktober 2002 (BGBl. I S. 4197), die zuletzt durch Artikel 5 des Gesetzes vom 17. Juli 2017 (BGBl. I S. 2394) geändert worden ist [Price Indication Ordinance in the version published on October 18, 2002 (BGB1. I p. 4197), as last amended by Article 5 of the Act of July 17, 2017 (BGB1. I p. 2394)]; 2017. German. Available from: https://www.gesetze-im-internet.de/pangv/ PAngV.pdf. Accessed May 10, 2021.

9. Keller ML. Angabe von Grundpreisen: In welchen Fällen sind Grundpreise entbehrlich? [Indication of Basic Prices: In Which Cases are Basic Prices Dispensable?]; 2013. German. Available from: https://www.it-recht-kanzlei.de/keine-angabe-grundpreiseerforderlich.html. Accessed May 10, 2021.

10. Deutscher Bundestag. Petition 72823. Arzneimittelpreise Preisauszeichnungspflicht für Apotheken [Petition 72823. Drug Prices - Mandatory Pricing for Pharmacies]; 2017. German. Available from: https://epetitionen.bundestag.de/petitionen/_2017/_ 07/_26/Petition_72823.nc.html. Accessed May 10, 2021.

11. Björnsdottir I, Granas AG, Bradley A, et al. A systematic review of the use of simulated patient methodology in pharmacy practice research from 2006 to 2016. Int J Pharm Pract. 2020;28(1):13-25. doi:10.1111/ijpp. 12570

12. Statistisches Bundesamt. Daten aus dem Gemeindeverzeichnis. Städte in Deutschland nach Fläche, Bevölkerung und Bevölkerungsdichte [Data from the Municipal Directory. Cities in Germany by Area, Population and Population Density]; 2020. German. Available from: https://www.desta tis.de/DE/Themen/Laender-Regionen/Regionales/Gemeindeverzeichnis/ Administrativ/05-staedte.htmlhttps://www.destatis.de/DE/Themen/ Laender-Regionen/Regionales/Gemeindeverzeichnis/Administrativ/05staedte.html. Accessed May 2, 2021.

13. BAK - Bundesapothekerkammer. Information und Beratung im Rahmen der Selbstmedikation am Beispiel Kopfschmerzen [Information and Advice in the Context of Self-Medication Using the Example of Headaches]; 2019. German. Available from: https:// www.abda.de/fuer-apotheker/qualitaetssicherung/leitlinien/leitlinienund-arbeitshilfen/. Accessed May 2, 2021.

14. Morris CJ, Cantrill JA, Weiss MC. "One simple question should be enough": consumers' perceptions of pharmacy protocols. Int J Pharm Pract. 1997;5(2):64-71. doi:10.1111/j.2042-7174.1997.tb00887.x

15. Anyama N, Adome RO. Community pharmaceutical care: an 8-month critical review of two pharmacies in Kampala. Afr Health Sci. 2003;3(2):87-93.

16. Saunders RE. Pharmacists in general medical practice: a case study of clinical commissioning groups [dissertation]. Keele: Keele University; 2018. Available from: https://eprints.keele.ac.uk/5106/1/ SaundersDPharm2018.pdf. Accessed May 2, 2021.

17. Collins JC, Schneider CR, El-den S, et al. Self-care-seeking behaviors in the community pharmacy: a cross-sectional exit survey of Australian consumers. J Am Pharm Assoc. 2020;60(6):827-834. doi:10.1016/j.japh.2020.04.019

18. Haag G, Diener H-C, May A, et al. Self-medication of migraine and tension-type headache: summary of the evidence-based recommendations of the Deutsche Migräne und Kopfschmerzgesellschaft (DMKG), the Deutsche Gesellschaft für Neurologie (DGN), the Österreichische Kopfschmerzgesellschaft (ÖKSG) and the Schweizerische Kopfwehgesellschaft (SKG). J Headache Pain. 2011;12(2):201-217. doi:10.1007/s10194-010-0266-4

19. Field A. Discovering Statistics Using IBM SPSS Statistics. 5th ed. London: SAGE Publications Ltd; 2018.

20. Cohen J. Statistical Power for the Behavioral Sciences. 2nd ed. Hillsdale NJ: Erlbaum; 1988.

21. Hammad EA, Elayeh E, Tubeileh R, et al. A simulated patient study assessing over the counter supply and counseling in Jordan: responding to headache complaints. Int J Clin Pharm. 2018;40(5):982-986. doi:10.1007/s11096-018-0679-8
22. Netere AK, Erku DA, Sendekie AK, et al. Assessment of community pharmacy professionals' knowledge and counseling skills achievement toward headache management: a cross-sectional and simulatedclient based mixed study. J Headache Pain. 2018;19(1):96. doi:10.1186/s10194-018-0930-7

23. Mesquita AR, Bezerra de Oliveira Sá DA, Lima Santos APA, et al. Assessment of pharmacist's recommendation of non-prescription medicines in Brazil: a simulated patient study. Int J Clin Pharm. 2013;35(4):647-655. doi:10.1007/s11096-013-9787-7

24. Langer B, Kunow C. Medication dispensing, additional therapeutic recommendations, and pricing practices for acute diarrhea by community pharmacies in Germany: a simulated patient study. Pharm Pract (Granada). 2019;17(3):1579. doi:10.18549/pharmpract.20 19.3.1579Langer2016

25. Langer B, Bull E, Burgsthaler T, et al. Using the simulated patient methodology to assess counselling for acute diarrhoea - evidence from Germany. Z Evid Fortbild Qual Gesundhwes. 2016;112:19-26. doi:10.1016/j.zefq.2016.02.001

26. Ibrahim IR, Palaian S, Ibrahim MI. Assessment of diarrhea treatment and counseling in community pharmacies in Baghdad, Iraq: a simulated patient study. Pharm Pract (Granada). 2018;16 (4):1313. doi:10.18549/pharmpract.2018.04.1313

27. Alabid AHMA, Ibrahim MIM, Hassali MA. Do professional practices among Malaysian private healthcare providers differ? A comparative study using simulated patients. J Clin Diagn Res. 2013;7(12):2912-2916. doi:10.7860/jcdr/2013/6198.3789

28. Tavares MP, Foster AM. Emergency contraception in a public health emergency: exploring pharmacy availability in Brazil. Contraception. 2016;94(2):109-114. doi:10.1016/j.contraception.2016.04.006

29. Hernandez JH, Mbadu MF, Garcia M, et al. The provision of emergency contraception in Kinshasa's private sector pharmacies: experiences of mystery clients. Contraception. 2018;97(1):57-61. doi:10.1016/j.contraception.2017.08.001

30. Shigesato M, Elia J, Tschann M, et al. Pharmacy access to Ulipristal acetate in major cities throughout the United States. Contraception. 2018;97(3):264-269. doi:10.1016/j.contraception.2017.10.009

31. Zweifel P, Manning WG. Moral hazard and consumer incentives in health care. In: Culyer AJ, Newhouse JP, editors. Handbook of Health Economics. Vol. 1A. Amsterdam: Elsevier; 2000: 409-459. doi:10.1016/S1574-0064(00)80167-5

32. Duarte F. Price elasticity of expenditure across health care services. $J$ Health Econ. 2012;31(6):824-841. doi:10.1016/j.jhealeco.2 012.07.002

33. Babar ZUD, Grover P, Stewart J, et al. Evaluating pharmacists' views, knowledge, and perception regarding generic medicines in New Zealand. Res Social Adm Pharm. 2011;7(3):294-305. doi:10.1016/j.sapharm.2010.06.004

34. Basak SC, Sathyanarayana D. Exploring knowledge and perceptions of generic medicines among drug retailers and community pharmacists. Indian J Pharm Sci. 2012;74(6):571-575. doi:10.4103/ 0250-474x.110611

35. Mohammed AS, Woldekidan NA, Mohammed FA. Knowledge, attitude, and practice of pharmacy professionals on generic medicines in Eastern Ethiopia: a cross-sectional study. PLoS One. 2020;15(7): e0235205. doi:10.1371/journal.pone.0235205

36. Bate R, Jin GZ, Mathur A. Does price reveal poor-quality drugs? Evidence from 17 countries. J Health Econ. 2011;30(6):1150-1163. doi:10.1016/j.jhealeco.2011.08.006

37. Dunne SS. What do users of generic medicines think of them? A systematic review of consumers' and patients' perceptions of, and experiences with, generic medicines. Patient. 2016;9 (6):499-510. doi:10.1007/s40271-016-0176-x

38. Håkonsen $\mathrm{H}$, Wängberg $\mathrm{M}$, Alani $\mathrm{D}$, et al. Generic versus brand-name over-the-counter analgesics: knowledge and attitudes among Swedish pharmacy customers. J Pharm Policy Pract. 2020;13:60. doi:10.1186/s40545-020-00269-5 
39. Kyselovič J, Koscova E, Lampert A, et al. A randomized, double-blind, placebo-controlled trial of ibuprofen lysinate in comparison to ibuprofen acid for acute postoperative dental pain. Pain Ther. 2020;9(1):249-259. doi:10.1007/s40122-019-00148-1

40. GEHALT.de. Gehaltsbiographie 2019 [Salary Biography 2019]; 2019. German. Available from: https://cdn.gehalt.de/cms/ Gehaltsbiografie-2019.pdf. Accessed May 2, 2021.

41. Niehues J, Stockhausen M. Vermögensgrenzen: Große gruppenspezifische Unterschiede, IW-Kurzbericht, Nr. 105, Köln [Wealth Limits: Large Group-Specific Differences, IW Short Report, No. 105, Cologne]; 2020. German. Available from: https://www.iwkoeln.de/fileadmin/user_upload/ Studien/Kurzberichte/PDF/2020/IW-

Kurzbericht_2020_Vermoegensgrenzen.pdf. Accessed May 2, 2021.

42. Siang TC, Hassali MA, Saleem F, et al. Assessment of medicines price variation among community pharmacies in the state of Penang, Malaysia by using simulated client method. J Med Mark. 2014;14(23):115-124. doi:10.1177/1745790414564260

43. Converse L, Barrett K, Rich E, et al. Methods of observing variations in physicians' decisions: the opportunities of clinical vignettes. J Gen Intern Med. 2015;30(Suppl 3):S586-S594. doi:10.1007/s11606-015-3365-8

44. World Health Organization/Health Action International. Measuring Medicine Prices, Availability, Affordability and Price Components. $2^{\text {nd }}$ ed; 2008. Available from: https://www.who.int/medicines/areas/access/ OMS_Medicine_prices.pdf?ua=1. Accessed May 2, 2021.

45. Caamaño F, Ruano A, Figueiras A, et al. Data collection methods for analyzing the quality of the dispensing in pharmacies. Pharm World Sci. 2002;24(6):217-223. doi:10.1023/a:1021808923928

46. Amaratunge S, Harrison M, Clifford R, et al. Developing a checklist for reporting research using simulated patient methodology (CRiSP): a consensus study. Int $J$ Pharm Pract. 2021;29(3):218-227. doi:10.1093/ijpp/riaa002

47. Saba M, Diep J, Bittoun R, et al. Provision of smoking cessation services in Australian community pharmacies: a simulated patient study. Int J Clin Pharm. 2014;36(3):604-614. doi:10.1007/s11096014-9944-7
48. Bardage C, Westerlund T, Barzi S, et al. Nonprescription medicines for pain and fever - a comparison of recommendations and counseling from staff in pharmacy and general sales stores. Health Policy (New York). 2013;110(1):76-83. doi:10.1016/j.healthpol.2012.12.006

49. Rhodes KV, Miller FG. Simulated patient studies: an ethical analysis. Milbank Q. 2012;90(4):706-724. doi:10.1111/j.1468-0009.2012.00 680.x

50. BVM. Berufsverband Deutscher Markt- und Sozialforscher e.V. Richtlinie für den Einsatz von Mystery Research in der Markt- und Sozialforschung [Guideline for the Use of Mystery Research in Market and Social Research]; 2006. Available from: https://www. bvm.org/fileadmin/user_upload/Verbandsdokumente/Standesregeln RL_neu_2021/Richtlinie_Mystery_2006.pdf. Accessed May 1, 2021.

51. Fitzpatrick A, Tumlinson K. Strategies for optimal implementation of simulated clients for measuring quality of care in low- and middle-income countries. Glob Health Sci Pr. 2017;5(1):108-114. doi:10.9745/ghsp-d-16-00266

52. da Rocha CE, Bispo ML, Dos Santos AC, et al. Assessment of community pharmacists' counseling practices with simulated patients who have minor illness: a pilot study. Simul Healthc. 2015;10 (4):227-238. doi:10.1097/sih.0000000000000100

53. Kayshap KC, Nissen LM, Smith SS, et al. Management of over-thecounter insomnia complaints in Australian community pharmacies: a standardized patient study. Int J Pharm Pract. 2014;22(2):125-134. doi:10.1111/ijpp.12052

54. Mobark DM, Al-Tabakha MM, Hasan S. Assessing hormonal contraceptive dispensing and counseling provided by community pharmacists in the United Arab Emirates: a simulated patient study. Pharm Pract (Granada). 2019;17(2):1465. doi:10.18549/pharmpract.201 9.2.1465
ClinicoEconomics and Outcomes Research

\section{Publish your work in this journal}

ClinicoEconomics and Outcomes Research is an international, peerreviewed open-access journal focusing on Health Technology Assessment, Pharmacoeconomics and Outcomes Research in the areas of diagnosis, medical devices, and clinical, surgical and pharmacological intervention. The economic impact of health policy and health systems

\section{Dovepress}

organization also constitute important areas of coverage. The manuscript management system is completely online and includes a very quick and fair peer-review system, which is all easy to use. Visit

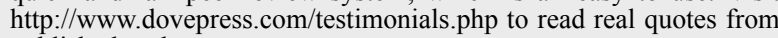
published authors. 